\title{
Radionuclide Contaminant Burdens in Arctic Marine Mammals Harvested During Subsistence Hunting
}

\author{
LEE W. COOPER, ${ }^{1}$ I.L. LARSEN,${ }^{2}$ TODD M. O'HARA, ${ }^{3}$ SCOTT DOLVIN,${ }^{4}$ VICTORIA WOSHNER ${ }^{5}$ and GLENN F. COTA ${ }^{6}$
}

\author{
(Received 2 July 1999; accepted in revised form 4 January 2000)
}

\begin{abstract}
We conducted gamma spectrometric analyses on more than 200 arctic marine mammal tissue samples. These samples were primarily provided by subsistence hunters from northern Alaska, with a smaller number of samples from the Resolute region in Canada. The majority of samples ( $>90 \%)$ had detectable levels of the anthropogenic radionuclide ${ }^{137} \mathrm{Cs}$, with a mean level observed in all samples of $0.67 \mathrm{~Bq} \mathrm{~kg}^{-1}$ dry weight \pm 0.81 (SD). Converted to wet weight, the mean was $0.21 \mathrm{~Bq} \mathrm{~kg}^{-1}$ $\pm 0.19 \mathrm{SD}$. The median activity observed was $0.45 \mathrm{~Bq} \mathrm{~kg}^{-1}$ dry weight $\left(0.18 \mathrm{~Bq} \mathrm{~kg}^{-1}\right.$ wet weight $)$ with a range from detection limits to $6.7 \mathrm{~Bq} \mathrm{~kg}^{-1}$ dry weight (1.1 Bq kg-1 wet weight). These findings confirm expectations that current anthropogenic gamma emitter burdens in marine mammals used in the North American Arctic as subsistence food resources are well below activities that would normally merit public health concern $\left(\sim 1000 \mathrm{~Bq} \mathrm{~kg}^{-1}\right.$ wet weight). Some differences among species and tissues were observed. Beluga tissues had slightly higher mean burdens of ${ }^{137} \mathrm{Cs}$ overall, and epidermis and muscle tissues in bowhead and beluga whales typically had higher burdens than other tissues analyzed. Low levels of the neutron activation product ${ }^{108 \mathrm{~m}} \mathrm{Ag}$ (half-life $418 \mathrm{yr}$.), probably bioaccumulated from bomb fallout sources, were observed in 16 of 17 beluga livers analyzed, but were not found in any other tissues of beluga or in any other species sampled. A subset of 39 samples of various tissues was analyzed for the alpha and beta emitters ${ }^{239,240} \mathrm{Pu}$ and ${ }^{90} \mathrm{Sr}$. Plutonium levels were near the threshold of detectability $\left(\sim 0.1 \mathrm{~Bq} \mathrm{~kg}^{-1}\right.$ dry weight $)$ in 6 of the 39

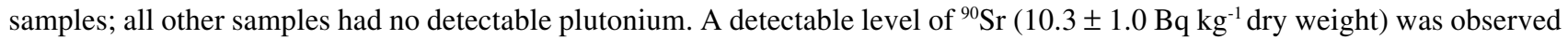
in only one of the 39 samples analyzed, a bowhead epidermis sample. Although the accumulation of ${ }^{108 \mathrm{~m}} \mathrm{Ag}$ has not been previously reported in any marine mammal livers, all of our analytical measurements indicate that only very low levels of anthropogenic radioactivity are associated with marine mammals harvested and consumed in the North American Arctic.
\end{abstract}

Key words: ${ }^{137} \mathrm{Cs}$, contamination, marine mammals, North Slope Borough, radioactivity, radionuclides, Resolute, ${ }^{108 m} \mathrm{Ag}$, subsistence hunting

RÉSUMÉ. On a effectué des analyses gamma-spectrométriques sur plus de 200 échantillons de tissus prélevés sur des mammifères marins. La plupart de ces échantillons étaient fournis par des chasseurs de subsistance de l'Alaska septentrional, et un petit nombre venaient de la région de Resolute au Canada. La majorité des échantillons ( $>90$ p. cent) contenaient des niveaux détectables du radionucléide anthropique ${ }^{137} \mathrm{Cs}$, avec un niveau moyen observé dans tous les échantillons de $0,67 \mathrm{~Bq} \bullet \mathrm{kg}^{-1} \mathrm{de}$ poids sec $\pm 0,81$ (écart-type). Convertie en poids frais, la moyenne était de $0,21 \mathrm{~Bq} \mathrm{~kg}^{-1} \pm 0,19 \mathrm{~d}$ 'écart-type. L'activité médiane observée était de $0,45 \mathrm{~Bq} \bullet \mathrm{kg}^{-1} \mathrm{de}$ poids sec $\left(0,18 \mathrm{~Bq} \bullet \mathrm{kg}^{-1}\right.$ de poids frais $)$ avec une fourchette allant des seuils de détection jusqu'à $6,7 \mathrm{~Bq} \bullet \mathrm{kg}^{-1}$ de poids sec $\left(1,1 \mathrm{~Bq} \bullet \mathrm{kg}^{-1}\right.$ de poids frais). Ces résultats confirment les réponses prévues, à savoir que les charges actuelles des émetteurs gamma anthropiques présentes chez les mammifères marins utilisés en Amérique du Nord comme ressource de subsistance sont bien inférieures aux niveaux qui voudraient normalement qu'on s'inquiète pour la santé publique $\left(\sim 1000 \mathrm{~Bq} \bullet \mathrm{kg}^{-1}\right.$ de poids frais). On a observé certaines différences dans les espèces et les tissus. Dans l'ensemble, les tissus prélevés sur le bélouga contenaient des charges moyennes de ${ }^{137} \mathrm{Cs}$ légèrement plus élevées, et l'épiderme et les tissus musculaires de la baleine boréale et du bélouga avaient généralement des charges supérieures à celles trouvées dans les autres tissus analysés. Dans 16 des 17 foies de bélouga analysés, on a observé de faibles niveaux du produit d'activation neutronique ${ }^{108 m} \mathrm{Ag}$ (demi-vie 418 années), dont la bioaccumulation est probablement due à des retombées de bombes atomiques, mais on n'en a observé aucune trace dans les autres tissus du bélouga ou de toute autre espèce échantillonnée. On a analysé un sous-ensemble de 39 échantillons provenant de tissus divers pour savoir s'ils contenaient des émetteurs alpha et bêta ${ }^{239,240}{ }^{2}{ }_{u}{ }^{~ e t ~}{ }^{90} \mathrm{Sr}$. Dans 6 des 39 échantillons, les niveaux de plutonium étaient proches du seuil de détectabilité $\left(\sim 0,1 \mathrm{~Bq} \bullet \mathrm{kg}^{-1}\right.$ de poids sec $)$, et on n'a pas trouvé de plutonium détectable dans aucun des

${ }^{1}$ Environmental Sciences Division, Oak Ridge National Laboratory, PO Box 2008, Oak Ridge, Tennessee 37831, U.S.A.; present address: Dept. of Ecology and Evolutionary Biology, University of Tennessee, Knoxville, Tennessee 37996, U.S.A.; lcooper@utkux.utk.edu

${ }^{2}$ Environmental Sciences Division, Oak Ridge National Laboratory, PO Box 2008, Oak Ridge, Tennessee 37831, U.S.A.; present address: Teledyne Brown Engineering, Inc., 2508 Quality Lane, Knoxville, Tennessee 37931-3133, U.S.A.

${ }^{3}$ Department of Wildlife Management, North Slope Borough, PO Box 69, Barrow, Alaska 99723, U.S.A.

${ }^{4}$ Department of Ecology and Evolutionary Biology, University of Tennessee, Knoxville, Tennessee 37996, U.S.A.; present address: TN \& Associates, 124 S. Jefferson Circle, Oak Ridge, Tennessee 37830, U.S.A.

${ }^{5}$ College of Veterinary Medicine, University of Illinois, Champaign-Urbana, Illinois 61801, U.S.A.

${ }^{6}$ Center for Coastal Physical Oceanography, Old Dominion University, Norfolk, Virginia 23508 U.S.A.

(C) The Arctic Institute of North America 
autres échantillons. On a observé un niveau détectable de ${ }^{90} \mathrm{Sr}\left(10,3 \pm 1,0 \mathrm{~Bq} \cdot \mathrm{kg}^{-1}\right.$ de poids sec $)$ dans un seul des 39 échantillons analysés, soit un échantillon d'épiderme de baleine boréale. Bien qu'on n'ait jamais rapporté auparavant une accumulation de

${ }^{108 \mathrm{~m}} \mathrm{Ag}$ dans le foie d'un mammifère marin, toutes nos mesures analytiques révèlent que les mammifères marins faisant l'objet d'une activité d'exploitation et consommés dans l'Arctique nord-américain ne présentent que de très faibles niveaux de radioactivité anthropique.

Mots clés: ${ }^{137} \mathrm{Cs}$, contamination, mammifères marins, North Slope Borough, radioactivité, radionucléides, Resolute, ${ }^{108 m} \mathrm{Ag}$, chasse de subsistance

Traduit pour la revue Arctic par Nésida Loyer.

\begin{abstract}
Аннотация. Был проведён гамма спектрометрический анализ 200 проб тканең морских арктических млекопитающих. Основная часть проб была предоставлена профессионапьными охотниками северной части Аляски и лишь небольшая их часть охватывала район Резолют в Канаде. В большей части проб (>90\%) содержатся измеримые количества радионукицда ${ }^{137} \mathrm{Cs}$ техногенного происхохдения со средним уровнем по всем пробам 0,67 Бк $\mathbf{~ T T}^{-1}$ сухого веса со стандяртным отклонением $\pm 0,81$. При пересчёте на влажный вес средний уровень составил 0,21 Бк кт ${ }^{-1}$ со стандартным отклоненнем $\pm 0,19$. Меднана составила 0,45 Бк $^{-1}$

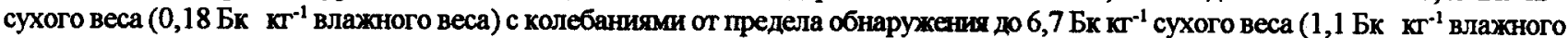
веса). Эти данные подтверждакот предположение о том, что радиоактивность, полученная морскими животными, являющимися объектом промысловой охоты в североамериканской части Арктики от источников гамма-изучения, значттельно ниже уровня активности, которая может вызывать обеспокоенность с точки зрения здоровья человека ( 1000 Бк кт сухого веса). Наблюдались нехоторые различия мехсду разными видами животных и разными тканями. В тканях белухи (Delphinapterus leucas) наблюдалось слегка повытенное среднее содержание ${ }^{137} \mathrm{Cs}$, а в этидермисе и мыптах гренландского кита (Balaena mysticetus) и белухи доза была выше, чем в любых других тканях, подвергнутых анализу. В 16 из 17 проб печени разных особей белухи наблюдалось низкое содержание продукта нейтронной активации ${ }^{108 x} \mathrm{Ag}$ (с периодом полураспада 418 лет), вероятно явившееся результатом биологического накопления, источником для которого послужиши радиоактивные выпадення в результате взрыва бомб, что не было отмечено ни в других тканях белухи, ни в пробах других видов животнх. Кроме того, был проведён анапиз выборки из 39 проб различшых тканей на альфа- и бета-изтучатели ${ }^{299.240} \mathrm{Pu}$ и ${ }^{90} \mathrm{Sr}$. Уровни содержания плутония в 6 из 39 проб были близки к порогу обнаружения $\left(\sim 0,1 \mathrm{bk} \mathrm{kT}^{-1}\right.$ сухого веса). В остапных пробах плутонй не был обнаружен. Измеримое содержание ${ }^{90} \mathrm{Sr}\left(10,3 \pm 1,0 \mathrm{bx} \quad\right.$ кт $^{-1}$ сухого веса) было обнаружено в 1 из 39 изученных про6 эпидермиса новозеландского кита. Хотя ранее проведённые исследования не обнаруживати ${ }^{104} \mathrm{Ag}$ в печени морских млекопитаюпих, напи анапитические измерения тем не менее показали наличе очень низих уровней активности техногенного происхождения в морских млекопитаюших, являющихся объектом промысловой охоты и продуктом питакия в североамериканской части Арктики.
\end{abstract}

Ключевые слова: радионукпиы, радиоактивность, морские млекопитаюшие, цезйи-137, серебро-108м, район Норт Слоуп, Резолют, загрязнение, промысловая охота

\section{INTRODUCTION}

The past decade has seen a renewed interest in the distribution and activity levels of radionuclides in arctic waters, sediments, and biota. Much of this recent work was initiated after 1992, when it became widely known that significant quantities of radioactive waste of former Soviet Union (FSU) origin had been dumped in the Arctic Ocean, the north Pacific, and in the East Asian marginal seas during the Cold War (Yablokov et al., 1993; Layton et al., 1997; AMAP, 1998). Potential radionuclide contributions to the Arctic Ocean from Russian nuclear fuel cycle and nuclear reprocessing sources on the $\mathrm{Ob}$ and Yenisey Rivers have also been studied recently (e.g., Aarkrog, 1994; Vakulovsky et al., 1995; Baskaran et al., 1995, 1996; Beasley et al., 1997; Cooper et al.,1999). These potential sources of Arctic anthropogenic radioactive contamination were in addition to a suite of three broadly defined anthropogenic sources that had been previously identified and studied. First, seminal work undertaken during the era of atmospheric testing of nuclear bombs demonstrated the relatively long biologically active half-life of radionuclides such as ${ }^{90} \mathrm{Sr}$ and ${ }^{137} \mathrm{Cs}$ in arctic tundra vegetation. This contamination resulted in significant radionuclide contaminant burdens in arctic herbivores such as caribou, which are used for subsistence by indigenous people of the Arctic (Hanson, 1967). Second, the transport into Arctic waters of by-products (including ${ }^{134} \mathrm{Cs},{ }^{137} \mathrm{Cs}$ and ${ }^{90} \mathrm{Sr}$ ) from nuclear fuel reprocessing in Western Europe (at La Hague in France and Sellafield in the United Kingdom) was documented in the 1970s and early 1980s (reviewed by Livingston, 1988; Kershaw and Baxter, 1995). Finally, the 1986 Chernobyl nuclear power plant accident in the former Soviet Union (FSU) resulted in the release of ${ }^{137} \mathrm{Cs}$, among other radionuclides, which contaminated tundra vegetation used by Komi reindeer herds in arctic Fennoscandia. This release had a significant impact upon reindeer, a locally important arctic economic resource and food asset (Huntington et al., 1998; Strand et al., 1998).

The 1992 revelations regarding FSU nuclear wastedisposal activities during the Cold War therefore did not signify a previously unforeseen threat to the safety of arctic subsistence food consumers. Rather, these revelations indicated that an additional source needed to be placed into context among all other radionuclide contaminant sources affecting the Arctic. A number of international 
programs have been conducted to study arctic radionuclide contaminant burdens in the 1990s. In the United States, Congress appropriated US\$30 million during 1993-95 for studies under the U.S. Arctic Nuclear Waste Assessment Program (ANWAP). One goal was to assess the possible health risks from radionuclide contaminants to subsistence users of marine food resources in Alaska (Layton et al., 1997). Despite this goal, relatively few data on radionuclide burdens in marine foods currently harvested by indigenous Arctic people have been available, and this shortcoming was acknowledged in the official U.S. government risk assessment (Layton et al., 1997). At the time that this risk assessment study was prepared, inferential and indirect data, including data on water and ice transport mechanisms, modeling, and water column distributions of radionuclides, were more readily available than data on distributions of radionuclides within biota. As a result, this risk assessment effort lacked biological compartments that would have led to a more complete and direct evaluation. Nevertheless, it was also apparent from a number of international research cruises that there was no evidence that nuclear waste materials dumped in the Kara Sea, the Sea of Japan (East Sea), the Sea of Okhotsk, and the north Pacific are currently leaking or otherwise releasing anthropogenic radionuclides in quantities that can be expected to significantly impact marine food webs in distant portions of the Arctic (AMAP, 1998).

The ANWAP and other recent, internationally based arctic radionuclide studies have been valuable in advancing our understanding of arctic oceanographic processes. Advances have included sea and ice transport mechanisms and water mass mixing, which provided model predictions that will be important if release rates of anthropogenic radionuclides sequestered in containers or in river sediments in the Russian Arctic change. Nevertheless, the direct users of arctic marine resources still do not have current data on radionuclide contaminant burdens in the foods that are harvested and consumed as part of the active subsistence economy present in many portions of the Arctic. Likewise, it is important to document current radionuclide contaminant burdens, particularly in subsistence food resources, to evaluate future trends.

To this end, we present data on radionuclide levels in various tissues and species of marine mammals harvested for food by Inuit hunters in the North Slope Borough of Alaska, as well as a smaller data set collected in the region around Resolute, Nunavut, Canada.

\section{MATERIALS AND METHODS}

In devising an analytical strategy, we initially undertook detection of gamma emitters, which can be counted directly with minimal sample preparation. Following these analyses, we analyzed a subset of samples by alpha spectroscopy. These same samples were also chemically separated for gross beta counting to provide representative data on several other radionuclides of potential interest, specifically plutonium and ${ }^{90} \mathrm{Sr}$. Although ${ }^{90} \mathrm{Sr}$, as a chemical analogue of calcium, can be expected to be concentrated in bone, our analyses of ${ }^{90} \mathrm{Sr}$ did not include bone tissue, as we examined only tissues normally consumed by subsistence users.

Following harvest in 1996 or 1997, marine mammal samples (typically 500-1000 g) were collected by the Department of Wildlife Management, North Slope Borough. Samples were then separated by tissue and species, homogenized with a commercial food processor, and placed into a $500 \mathrm{~mL}$ or $1000 \mathrm{~mL}$ high-density polyethylene Marinelli beaker (Gamma Associates) designed for direct gamma spectroscopy. The beakers were labeled, sealed, frozen, and shipped to the Environmental Sciences Division, Oak Ridge National Laboratory (ORNL), Oak Ridge, Tennessee. Preparation of Resolute (Canada) samples differed in that 200-500 g samples of tissue were dried in the field before shipment to Oak Ridge, so that only dry mass activities are available. Before counting, samples were in some cases repackaged to maximize the space within the container filled, thus assuring appropriate geometries and counting efficiency. Following wet weight determinations, samples were radio-assayed using low-background, highresolution, lithium drifted germanium or high purity germanium detectors equipped with a Canberra Genie personal computer system programmed to record the gamma spectra for one to 4096 channels. These detectors were shielded with layered lead and copper to minimize background radiation and $\mathrm{x}$-ray interference. Calibration of our detectors within the Environmental Sciences Division of ORNL was performed using certified mixed gamma standards with traceability to the National Institute of Standards and Technology (NIST). Background corrections were performed and control samples were analyzed daily to verify detector performance. The counting time was typically 48 hours or longer for each sample. After counting, samples were oven dried at $60^{\circ} \mathrm{C}$ for 24 to 72 hours to dryness, and the dry weights were recorded.

Alpha and beta spectroscopy for ${ }^{90} \mathrm{Sr}$ and ${ }^{239,240} \mathrm{Pu}$ was undertaken by the Analytical Services Organization, ORNL, and the Environmental Survey and Site Assessment Program (ESSAP) of the Oak Ridge Institute for Science and Education (ORISE). Dried samples were removed from the Marinelli beakers and digested, with about two-thirds of the sample subjected to high-temperature ashing in a muffle furnace at 500 to $650^{\circ} \mathrm{C}$. The ashed samples were then split in half, and ${ }^{239,240} \mathrm{Pu}$ determinations were made by alpha counting after treatment by acid digestion, separation by ion exchange, and electro-deposition onto stainless steel disks (Laudeman et al., 1995). For the separate ${ }^{90} \mathrm{Sr}$ determinations, digestion was achieved by high-temperature fusion with anhydrous potassium fluoride and pyrosulfate over a burner. Carrier solutions were added, and the sample was then dissolved in $\mathrm{HCl}$ and the ${ }^{90} \mathrm{Sr}$ separated from ${ }^{90} \mathrm{Y}$. The strontium sulfate was purified and then deposited onto the planchet. The samples 
were beta counted and then recounted, allowing for ingrowth of the radiostrontium daughter product, yttrium. Following determination of all counts and yields, activities were calculated as follows:

$$
\text { Activity }=\frac{G-B}{(t)(Q)(Y)(E)}
$$

where $G$ was the gross count, $B$ was the background count, $t$ was the count time, $Q$ was the sample quantity, $Y$ was the chemical yield, and $E$ was the ${ }^{90} \mathrm{Y}$ counting efficiency, with adjustments made for the ingrowth of yttrium calculated by $\left[1-\mathrm{e}^{-(\ln 2 / 64.1) \mathrm{T}}\right]$, where $\mathrm{T}$ is the yttrium ingrowth time. Minimum detectable activities for ${ }^{90} \mathrm{Sr}$ varied among samples depending upon counting time and sample size, but were typically $\sim 0.1$ to $0.6 \mathrm{~Bq} \mathrm{~kg}^{-1}$. Additional details on controls and quality assurance undertaken in the course of these measurements are available in Laudeman et al. (1995).

Analysis of variance was used to test for differences among tissues and species, with the Scheffé test used specifically to evaluate the differences between pairs of sample groups. The Scheffé test, also known as the Smethod (Scheffé, 1959) was chosen for the comparisons because it does not require identification of possible comparisons before measurement, it is conservative in identifying significant differences, and it does not require equal sample sizes (see discussion in Lindman, 1992).

\section{RESULTS}

In the samples analyzed, we detected only two anthropogenic gamma emitters, ${ }^{137} \mathrm{Cs}$ (half-life 30.2 years) and ${ }^{108 \mathrm{~m}} \mathrm{Ag}$ (half-life 418 years), and ${ }^{137} \mathrm{Cs}$ was by far the more common. Identification of ${ }^{137} \mathrm{Cs}$ in a gamma spectrum is routine in environmental gamma spectroscopy, but we undertook several precautions to ensure accurate identification of the metastable, excited nuclear isomer of ${ }^{108 \mathrm{~m}} \mathrm{Ag}$ in our samples (the ground state isotope to which ${ }^{108 \mathrm{~m}} \mathrm{Ag}$ decays is ${ }^{108} \mathrm{Ag}$, and it has a half-life of 2.7 minutes). Specifically, we identified ${ }^{108 \mathrm{~m}} \mathrm{Ag}$ on the basis of the three dominant gamma emitters in the spectrum, $432.9 \mathrm{keV}$, $614.4 \mathrm{keV}$, and $723 \mathrm{keV}$, with photon intensities of $89.9 \%$, $90.4 \%$, and $90.5 \%$, respectively. Given virtually identical activities, there was no other likely nuclide that could have produced the observed spectrum (see Larsen, 1998). Quality assurance was provided by another gamma spectroscopy laboratory within Oak Ridge National Laboratory, which provided a blind confirmation of the presence of ${ }^{108 m} \mathrm{Ag}$ in samples where we also detected it. In evaluating the presence of this isotope in our samples, we use here the most recently available estimate of its half-life, 418 years (Tuli, 1995).

Low levels of this radiosilver isotope, ${ }^{108 \mathrm{~m}} \mathrm{Ag}$, from 0.12 $\pm 0.02(1 \sigma)$ to $5.86 \pm 0.13 \mathrm{~Bq} \mathrm{~kg}^{-1}$ dry weight, were detected in 16 of 17 beluga livers that were subjected to gamma spectroscopy. These samples all originated from the North Slope Borough. This radionuclide was not observed in any other tissue in belugas, nor was it found in any other species studied. Using trace metal and demographic data for these samples (V. Woshner et al., unpubl. data) we found no relationship between radiosilver activities and age, sex, or location of harvest. However, we did observe a significant relationship ( $p=0.002)$ between radiosilver activities and the total elemental silver present in individual livers (Fig. 1).

Radiocesium concentrations in all biotic samples were very low, with mean and median activities less than $1 \mathrm{~Bq} \mathrm{~kg}^{-1}$ dry weight in most instances (Table 1). Among tissues in all species of marine mammals analyzed, ${ }^{137} \mathrm{Cs}$ activities in blubber were almost always undetectable. Analysis of variance indicates that in bowhead and beluga whales, ${ }^{137} \mathrm{Cs}$ burdens were significantly higher in epidermis and muscle tissue than in liver and kidney tissue within each species (Table 2). There were no obvious geographical differences in ${ }^{137} \mathrm{Cs}$ activities between marine mammals harvested in Resolute and those from the North Slope Borough (Table 1). In kidney tissue, ${ }^{137} \mathrm{Cs}$ activities were significantly higher in belugas than in bowhead whale, polar bear, and ringed seal (Table 3 ).

A few samples had detectable activities of ${ }^{90} \mathrm{Sr}$ and ${ }^{239,240} \mathrm{Pu}$. In one bowhead whale epidermis sample, ${ }^{90} \mathrm{Sr}$ was present at a detectable level, $10.3 \pm 1.0(2 \sigma) \mathrm{Bq} \mathrm{kg}^{-1}$ dry weight. In 38 other samples, including four additional bowhead epidermis samples, and in various tissues from six species of marine mammals, ${ }^{90} \mathrm{Sr}$ was not detectable. In subsamples of the same tissues assayed by alpha spectrometry for ${ }^{239,240} \mathrm{Pu}$, detectable activities were observed, on the basis of minimum detectable activities and the error terms associated with each measurement, in at most six samples. These samples were specifically a beluga epidermis sample, separate bowhead whale blubber, epidermis, and muscle samples, and separate polar bear and ringed seal muscle samples. In all cases, the ${ }^{239,240} \mathrm{Pu}$ activities were just above detection limits $\left(<0.1 \mathrm{~Bq} \mathrm{~kg}^{-1}\right.$ dry weight), even after adding a positive $2 \sigma$ counting error to each observed activity.

\section{DISCUSSION}

These data demonstrate that anthropogenic radioisotopes are present at detectable levels in marine mammals harvested for subsistence food in northern Alaska and in the Resolute, Canada, region. However, the activities we observe are currently orders of magnitude below levels that would merit public health concern $\left(1000 \mathrm{~Bq} \mathrm{~kg}^{-1}\right.$ is the guideline of the Food and Agriculture Organization of the United Nations/World Health Organization Codex Alimentarius Commission). The activities are also lower than ${ }^{137} \mathrm{Cs}$ burdens in marine mammals (up to $66 \mathrm{~Bq} \mathrm{~kg}^{-1}$ wet weight) in the regions of the north Atlantic affected by nuclear waste discharges from the Sellafield, U.K. nuclear fuel reprocessing plant into the Irish Sea (Watson et al., 1999). Comparing to other arctic subsistence food resources, 


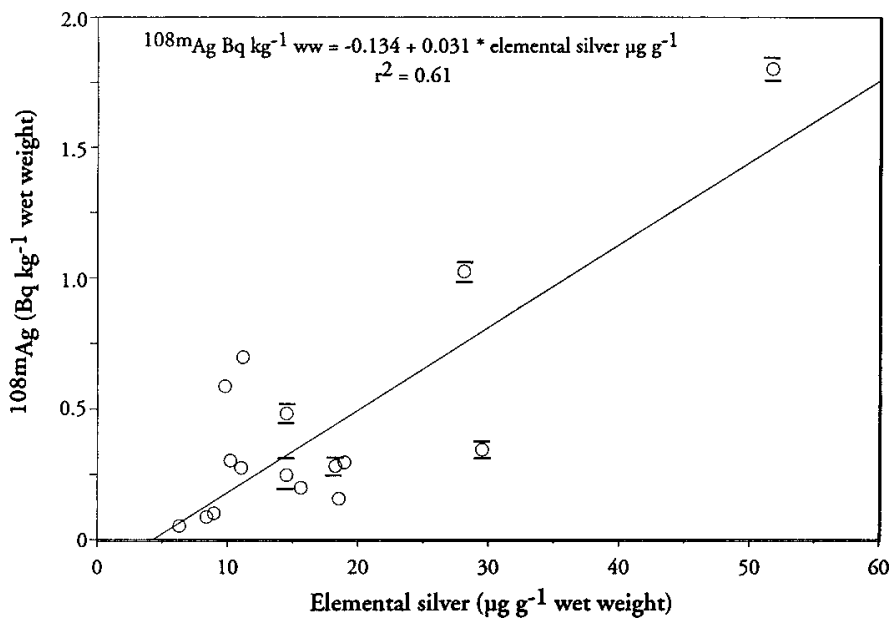

FIG. 1. Activity of ${ }^{108 \mathrm{~m}} \mathrm{Ag}$ wet weight relative to elemental silver concentrations in 16 beluga livers (circles) for which both data sets were available. A representation of the error $( \pm 2 \sigma)$ is shown only where the magnitude of the error extends beyond the diameter of the circles used as symbols. Nine animals ( 5 female, 4 male) were harvested at Point Lay, Alaska, six ( 2 female, 4 male) at Point Hope, and one (male) at Barrow.

activities of ${ }^{137} \mathrm{Cs}$ in the marine mammals we assayed are two to three orders of magnitude below recently reported levels in caribou in northern Canada and Alaska (Macdonald et al., 1996; O'Hara et al., 1999). Even these ${ }^{137}$ Cs activities have declined significantly from maxima at the time of nuclear weapons testing, when ${ }^{137} \mathrm{Cs}$ activities in lichens and caribou flesh in excess of $1000 \mathrm{~Bq}$ per g dry weight (rather than per kg) were readily observed (Hanson, 1967). The activities of ${ }^{137} \mathrm{Cs}$ in marine mammals that we report here are also as much as five orders of magnitude below levels reported on a wet weight basis in reindeer in Fennoscandia following the Chernobyl accident in 1986 (Eikelmann et al., 1990; Åhman and Åhman, 1994).

While our results were not unanticipated, given other analyses of current radionuclide contamination in sediments and waters in the North American Arctic (e.g., Medinets et al., 1992; Baskaran and Naidu, 1995; Cooper et al., 1995, 1998), several of our observations suggest variations in the extent to which anthropogenic radionuclides are incorporated by different animal species and tissues. We consider first the activities of ${ }^{137} \mathrm{Cs}$ dissolved in surface waters of the Bering, Chukchi, and Beaufort Seas, which currently range from less than 1 to $4 \mathrm{~Bq} \mathrm{~m}^{-3}$ (Medinets et al., 1992; L. Cooper, unpubl. data, 1994-95). Thus, activities of ${ }^{137} \mathrm{Cs}$ in biota of less than $1 \mathrm{~Bq} \mathrm{~kg}^{-1}$ wet weight (Table 1) represent a concentration of radiocesium that is nearly three orders of magnitude greater than levels observed in seawater (by wet mass). This difference of three orders of magnitude is consistent with partitioning coefficients $\left(\mathrm{K}_{\mathrm{d}}\right)$ observed for cesium in laboratory-scale studies using phytoplankton (Fisher, 1985), but it is larger than the radiocesium concentration factors of one to two orders of magnitude observed between marine fishes and seawater in a recent comprehensive study undertaken in Japan (Kasamatsu and Ishikawa, 1997). However, Kasamatsu and Ishikawa (1997) indicated that concentration factors approach three orders of magnitude between radiocesium in seawater and biotic concentrations in the highest trophic levels, particularly for organisms that consume large fish. A similar factor of 300 was recently observed for the differences between water column ${ }^{137} \mathrm{Cs}$ activities and wetweight tissues of seals and porpoises in marine waters of the British Isles (Watson et al., 1999). In our study, slightly higher mean ${ }^{137} \mathrm{Cs}$ activities observed in some beluga whale tissues (Table 1) might be related to feeding patterns, since these animals commonly feed upon fish in inshore areas, including estuarine lagoons (Hazard, 1988). Freshwater and estuarine fish typically have higher radiocesium burdens than stenohaline species (see Avery, 1996; Kasamatsu and Ishikawa, 1997, and references therein). These high burdens are likely due to competition for cesium absorption from other, more chemically abundant alkali metals (e.g., Na, K) in marine systems, leading to long residence times for dissolved cesium before it is absorbed onto particles (Olsen et al., 1993). This difference in the chemical behavior of cesium between freshwater and marine systems has resulted in higher inventories of ${ }^{137} \mathrm{Cs}$ in Alaska arctic soils (Cooper et al., 1995) than in Alaska arctic marine sediments (Cooper et al., 1998). On a tissue basis, the higher mean activities of ${ }^{137} \mathrm{Cs}$ observed in beluga and bowhead muscle and epidermis (Table 2) may be due to a higher concentration of the chemical analog potassium in those tissues, although we did not assay our samples for potassium concentrations. When separated on a tissue basis, kidneys of belugas had significantly higher ${ }^{137} \mathrm{Cs}$ activities than kidneys from other species examined, although sample size limitations prevent more extensive comparisons.

Although our study did not explicitly consider the trophic levels of the animals harvested, there are indications that there may be a food-web basis for some interspecific differences in anthropogenic radioactivity. For example, in contrast to the marine mammal tissues we examined, detection of ${ }^{137} \mathrm{Cs}$ in lower trophic levels such as zooplankton and benthic invertebrates in the Arctic Ocean is more the exception than the rule (L. Cooper, I.L. Larsen, G.F. Cota, and J.M. Grebmeier, unpubl. data). This indicates some degree of bioaccumulation between lower and higher trophic levels. The highest single marine mammal ${ }^{137} \mathrm{Cs}$ activity we observed $\left(6.7 \mathrm{~Bq} \mathrm{~kg}^{-1}\right.$ dry weight) was in a muscle-tissue sample of a top carnivore, polar bear. Nevertheless, in the relatively small number of polar bear tissues assayed, we did not observe that the mean radioactivity was systematically higher than in other marine mammals (Table 1). Additional sampling from a food web orientation (e.g., stable isotopes, fatty acid analyses, etc.) might help determine the importance of trophic level in affecting radionuclide contaminant burdens.

The observations of ${ }^{108 \mathrm{~m}} \mathrm{Ag}$ in the majority of beluga livers sampled are unusual because this nuclide is rare. We did not detect it in other tissues or species in this study or in any of the hundreds of Arctic sediments and water samples we have analyzed over the past decade. The 
TABLE 1. Activities of ${ }^{137}$ Cs observed in arctic organisms sampled in 1995-97 from northern Alaska and Resolute, Canada. Activities are decay-corrected to the date of collection. n.d. = not detected.

\begin{tabular}{|c|c|c|c|c|}
\hline $\begin{array}{l}\text { Species } \\
\text { Tissue }\end{array}$ & $\begin{array}{c}\text { Maximum }{ }^{137} \mathrm{Cs} \\
\text { activity observed } \\
\left(\mathrm{Bq} \mathrm{kg}^{-1} \text { dry weight }\right)\end{array}$ & $\begin{array}{l}\text { Mean }{ }^{137} \mathrm{Cs} \text { activity } \\
\left(\mathrm{Bq} \mathrm{kg}^{-1} \text { dry weight }\right. \\
\pm \text { standard deviation }\end{array}$ & $\begin{array}{l}\text { Mean }{ }^{137} \text { Cs activity } \\
\text { (Bq kg wet weight) } \\
\pm \text { standard deviation }\end{array}$ & $\begin{array}{c}\text { Collection locations } \\
\text { (number of samples assayed } \\
\text { from each location) }\end{array}$ \\
\hline \multicolumn{5}{|c|}{ Bowhead whale, Balaena mysticetus ${ }^{1}$} \\
\hline All tissues & 1.51 & $0.46 \pm 0.38$ & $0.13 \pm 0.10$ & North Slope Borough (61) \\
\hline blubber & - & n.d. & n.d. & 9 \\
\hline epidermis & 1.51 & $0.69 \pm 0.41$ & $0.19 \pm 0.10$ & 12 \\
\hline muscle & 1.18 & $0.72 \pm 0.25$ & $0.23 \pm 0.08$ & 14 \\
\hline kidney & 0.86 & $0.44 \pm 0.24$ & $0.12 \pm 0.06$ & 13 \\
\hline liver & 0.41 & $0.19 \pm 0.13$ & $0.08 \pm 0.05$ & 13 \\
\hline \multicolumn{5}{|l|}{ Beluga, Delphinapterus leucas ${ }^{2}$} \\
\hline All tissues & 3.16 & $1.17 \pm 0.76$ & $0.38 \pm 0.23$ & $\begin{array}{l}\text { North Slope Borough (58) } \\
\text { and Resolute (3) }\end{array}$ \\
\hline blubber & - & n.d. & n.d. & 5 \\
\hline epidermis & 2.11 & $1.05 \pm 0.41$ & $0.41 \pm 0.41$ & 14 \\
\hline muscle & 2.66 & $1.93 \pm 0.43$ & $0.61 \pm 0.13$ & 13 \\
\hline kidney & 2.81 & $1.50 \pm 0.67$ & $0.40 \pm 0.17$ & 12 \\
\hline liver & 3.16 & $0.81 \pm 0.66$ & $0.27 \pm 0.22$ & 17 \\
\hline \multicolumn{5}{|c|}{ Bearded seal, Erignathus barbatus ${ }^{3}$} \\
\hline All tissues & 1.23 & $0.64 \pm 0.44$ & & $\begin{array}{l}\text { North Slope Borough (3) } \\
\text { and Resolute (3) }\end{array}$ \\
\hline muscle & 1.23 & $0.80 \pm 0.47$ & - & 4 \\
\hline kidney & 0.44 & 0.44 & - & 1 \\
\hline liver & 0.23 & 0.23 & 0.10 & 1 \\
\hline \multicolumn{5}{|l|}{ Ringed seal, Phoca hispida ${ }^{4}$} \\
\hline All tissues & 1.11 & $0.34 \pm 0.34$ & $0.11 \pm 0.10$ & $\begin{array}{l}\text { North Slope Borough (36) } \\
\text { and Resolute (1) }\end{array}$ \\
\hline blubber & $<0.01$ & $<0.01$ & $<0.01$ & 7 \\
\hline muscle & 1.03 & $0.60 \pm 0.26$ & $0.21 \pm 0.05$ & 11 \\
\hline kidney & 1.08 & $0.20 \pm 0.40$ & $0.04 \pm 0.07$ & 8 \\
\hline liver & 1.11 & $0.40 \pm 0.29$ & $0.16 \pm 0.08$ & 11 \\
\hline \multicolumn{5}{|l|}{ Polar bear, Ursus maritimus ${ }^{5}$} \\
\hline All tissues & 6.70 & $0.63 \pm 0.97$ & & $\begin{array}{l}\text { North Slope Borough (49) } \\
\text { and Resolute (3) }\end{array}$ \\
\hline blubber & $<0.01$ & $<0.01$ & $<0.01$ & 7 \\
\hline muscle & 6.70 & $1.39 \pm 1.59$ & $0.31 \pm 0.10$ & 14 \\
\hline kidney & 0.81 & $0.44 \pm 0.26$ & $0.15 \pm 0.09$ & 13 \\
\hline liver & 1.08 & $0.49 \pm 0.34$ & $0.22 \pm 0.15$ & 15 \\
\hline oil & n.d. & n.d. & n.d. & 3 \\
\hline \multicolumn{5}{|l|}{ Spotted seal, Phoca vitulina ${ }^{6}$} \\
\hline All tissues & 1.32 & $1.02 \pm 0.39$ & & North Slope Borough (4) \\
\hline muscle & 1.16 & 1.16 & 0.34 & 1 \\
\hline kidney & 1.32 & $1.23 \pm 0.13$ & $0.33 \pm 0.23$ & 2 \\
\hline liver & 0.45 & 0.45 & 0.20 & 1 \\
\hline Walrus, Odobenus rosmarus ${ }^{7}$ & 0.43 & 0.43 & & Resolute (1) \\
\hline Narwhal, Monodon monoceros 8 & 0.68 & $0.62 \pm 0.09$ & & Resolute (2) \\
\hline
\end{tabular}

${ }^{1}$ Samples obtained from 14 individual animals (3 male, 11 female), harvested in April-September 1996 and 1997.

${ }^{2}$ Samples obtained from 18 individual animals (9 male, 9 female), harvested in July-August 1996 and 1997.

${ }^{3}$ Samples obtained from 4 individual animals (one from North Slope Borough and three from Resolute).

${ }^{4}$ Samples obtained from 12 individual animals (7 male, 4 female, 1 unknown); all North Slope Borough animals harvested in July 1996.

${ }^{5}$ Samples obtained from 22 individual animals (9 male, 8 female, 5 unknown); North Slope Borough animals harvested in MarchDecember 1996.

${ }^{6}$ Samples obtained from one male animal harvested on 26 June 1996.

${ }^{7}$ Samples obtained from one individual animal.

${ }^{8}$ Samples obtained from two individual animals. 
TABLE 2. Scheffé test for differences among tissues of marine mammal species, mean dry weight ${ }^{137} \mathrm{Cs}$ burden, as tabulated in Table 1. This table includes only significant differences within each species $(p<0.05)$.

\begin{tabular}{lccc}
\hline \hline Comparison & $\begin{array}{c}\text { Mean difference } \\
\text { (First tissue - second tissue) }\end{array}$ & Critical difference & $p$ \\
\hline $\begin{array}{c}\text { Bowhead whale, Balaena mysticetus } \\
\text { blubber - skin }\end{array}$ & -0.69 & 0.40 & 0.0001 \\
blubber - muscle & -0.72 & 0.40 & $<0.0001$ \\
blubber - kidney & -0.44 & 0.41 & 0.025 \\
skin - liver & 0.50 & 0.38 & 0.004 \\
muscle - liver & 0.53 & 0.38 & 0.002 \\
Beluga, Delphinapterus leucas & & & \\
blubber - skin & -1.05 & 0.97 & 0.026 \\
blubber - muscle & -1.93 & 0.98 & $<0.0001$ \\
blubber - kidney & -1.50 & 0.99 & 0.0004 \\
skin - muscle & -0.88 & 0.72 & 0.0064 \\
muscle - liver & 1.12 & 0.68 & 0.001 \\
Ringed seal, Phoca hispida & & & \\
blubber - muscle & -0.59 & 0.50 & 0.012 \\
\hline \hline
\end{tabular}

activities that we observed, $0.12 \pm 0.02$ to $5.86 \pm 0.13$ $\mathrm{Bq} \mathrm{kg}{ }^{-1}$, constitute no significant human health hazard, since they are of the same magnitude as the low levels of ${ }^{137} \mathrm{Cs}$ observed, and the radiosilver occurs in only one tissue, liver, and one species, beluga. ${ }^{108 \mathrm{~m}} \mathrm{Ag}$ is a product of neutron activation of the two natural isotopes of silver $\left({ }^{107} \mathrm{Ag}, 51.35 \% ;{ }^{109} \mathrm{Ag}, 48.65 \%\right)$. Neutron activation of ${ }^{109} \mathrm{Ag}$ also produces ${ }^{110 \mathrm{~m}} \mathrm{Ag}$, but its half-life is much shorter $(252 \mathrm{~d})$, and it was not detected in any samples. While we are not aware of any other reports of its detection during recent Arctic sampling, ${ }^{108 \mathrm{~m}} \mathrm{Ag}$ was detected as a bomb fallout product concentrated in marine organisms following atmospheric nuclear weapons tests in the Pacific (Beasley and Held, 1971). Analyses of ${ }^{110 \mathrm{~m}} \mathrm{Ag} /{ }^{108 \mathrm{~m}} \mathrm{Ag}$ activity ratios in these Pacific biological specimens relative to the timing of atmospheric nuclear tests indicate that most environmental ${ }^{108 \mathrm{~m}} \mathrm{Ag}$ was produced during weapons tests. It resulted from neutron reactions acting on silver impurities in the natural uranium cladding or the steel structural materials surrounding the fission/fusion devices and on natural silver in electronic circuitry associated with the devices (Folsom et al., 1970; Grismore et al., 1972). The activities of ${ }^{108 \mathrm{~m}} \mathrm{Ag}$ that we report here are within the range reported for a number of marine biological samples analyzed by Grismore et al. (1972). They observed a maximum ${ }^{108 \mathrm{~m}} \mathrm{Ag}$ activity of $4.8 \mathrm{~Bq} \mathrm{~kg}^{-1}$ wet weight for a squid collected in the northeast Pacific. Most of the ${ }^{108 \mathrm{~m}} \mathrm{Ag}$ activities reported by Grismore et al. (1972) were for livers from albacore from both the Pacific and Atlantic Oceans. The ${ }^{108 \mathrm{~m}} \mathrm{Ag}$ activities in squid were also associated with digestive organs. Given the free-ranging distribution of both albacore and squid, we hypothesize that the source of the ${ }^{108 \mathrm{~m}} \mathrm{Ag}$ activities we observe in beluga whale livers is also a result of a bioaccumulation of radiosilver derived ultimately from bomb testing. Stratospheric bomb fallout (rather than more recently derived nuclear waste materials)
TABLE 3. Scheffé test for differences among species of marine mammals for kidney tissues, mean dry weight ${ }^{137} \mathrm{Cs}$ burden, as tabulated in Table 1. This table includes only significant differences within each species $(p<0.05)$. No significant differences among species were observed in separate muscle, liver, blubber, and epidermis comparisons.

\begin{tabular}{lccc}
\hline \hline Comparison & $\begin{array}{c}\text { Mean difference } \\
\text { (First species - second species) }\end{array}$ & Critical difference & $p$ \\
\hline Kidney & & & \\
bowhead whale - beluga & -0.72 & 0.40 & $<0.0001$ \\
beluga - ringed seal & 1.30 & 0.76 & $<0.0001$ \\
beluga - polar bear & 0.50 & 0.38 & 0.004 \\
\hline \hline
\end{tabular}

is consistent as a source because we did not detect in our samples the much shorter-lived radionuclide ${ }^{110 \mathrm{~m}} \mathrm{Ag}$, which we might also expect to detect following neutron activation of natural silver. However, because the length of time that has elapsed since the cessation of nuclear testing is much longer than the half-life of ${ }^{110 \mathrm{~m}} \mathrm{Ag}$ (252 d), it is not possible to completely rule out an independent source of radiosilver in the Arctic, such as nuclear waste.

Independent trace metal analyses of these samples, to be presented elsewhere (V. Woshner et al., unpubl. data), as well as published data (Becker et al., 1995; Mackey et al., 1996), indicate that belugas effectively bioaccumulate silver (and other trace metals) within liver tissue. The mean concentration of elemental silver in the 16 beluga livers we radioassayed was $17.3 \mu \mathrm{g} \mathrm{g}^{-1} \pm 11.0 \mathrm{SD}$, compared, for example, to a mean concentration below $0.1 \mu \mathrm{g} \mathrm{g}^{-1}$ in ringed seal liver. In addition, a significant relationship ( $p=0.002)$ between total silver concentrations and ${ }^{108 \mathrm{~m}} \mathrm{Ag}$ activities was observed in beluga livers where both analyses were undertaken (Fig. 1). We hypothesize that the presence of ${ }^{108 \mathrm{~m}} \mathrm{Ag}$ is a direct consequence of the observed bioaccumulation of elemental silver within beluga tissues, although the strength of the correlation $\left(r^{2}=0.61\right.$; Fig. 1$)$ is not as robust as might be expected because the absolute radioactivities are so low. Additional gamma spectroscopy of beluga livers from other locations (e.g., eastern Canada, including the Gulf of St. Lawrence) might help to establish definitively that the presence of ${ }^{108 m} \mathrm{Ag}$ in this tissue is widespread, and that it is a consequence of stratospheric bomb fallout rather than originating from a local Arctic source.

Anthropogenic radioactive contamination of the Arctic has been the subject of wide concern. Studies of radioisotope distributions have been incorporated into the internationally sponsored Arctic Monitoring and Assessment Programme (AMAP, 1998). Our findings presented here should help put the problem in an appropriate perspective for subsistence consumers in North America. For example, the few instances where ${ }^{90} \mathrm{Sr}$ and ${ }^{239,240} \mathrm{Pu}$ were present near detection limits indicate that these anthropogenic radionuclides are not currently present at any levels that merit concern. In general, our results indicate that the current human health risk from anthropogenic radionuclides 
in marine mammal food resources is very likely to be negligible. Future work may be better directed towards the much larger or uncertain degrees of potential risk from other classes of contaminants in the Arctic, including organochlorines, polycyclic aromatic hydrocarbons, and metals (Macdonald and Bewers, 1996).

\section{ACKNOWLEDGEMENTS}

We greatly appreciate the cooperation of the Alaska Eskimo Whaling Commission and the many hunters, whaling captains, and crews in Point Hope, Point Lay, and Barrow, who provided the samples that were analyzed as part of this study. We specifically thank Benny Akootchek, Tom Albert, Perry "Qaavik”Anashugak, Paul Becker, Kimberlee Beckmen, Charles D.N. Brower, Harry Brower, Jr., Craig George, Carl Kippi, Paul Nader, Dave Ramey, Teri Rowles, Robert Suydam, Carla Willetto, and Geoff York for assistance with logistical support and sample collection. We thank Ed Landa (U.S. Geological Survey), Warren Webb (Oak Ridge National Laboratory), Thomas G. Hinton (Savannah River Ecology Laboratory), Jawed Hameedi (National Oceanic and Atmospheric Administration), and Jesse Ford (Oregon State University) for reviewing and providing comments on earlier versions of the manuscript. We thank Carolina B. Ravina (Oak Ridge National Laboratory) for preparing the Russian language abstract. Financial support was provided by U.S. Office of Naval Research (ONR) Grant Number N00014-96-1-0797 to the Department of Wildlife Management of the North Slope Borough, and additional support was provided directly by the North Slope Borough. Financial support to Old Dominion University was provided by Contract N00014-95-1-1196 with ONR. Work undertaken at Oak Ridge National Laboratory was supported through Agreement ERD-96421 between the U.S. Department of Energy and the North Slope Borough. At the time of this study, Oak Ridge National Laboratory was operated for the U.S. Department of Energy by the Lockheed Martin Energy Research Corp. under Contract DE-AC0596OR22464. Environmental Sciences Division Publication 4986.

\section{REFERENCES}

AARKROG, A. 1994. Radioactivity in polar regions: Main sources. Journal of Environmental Radioactivity 25:21-35.

ÅHMAN, B., and ÅHMAN, G. 1994. Radiocesium in Swedish reindeer after the Chernobyl fallout: Seasonal variations and long-term decline. Health Physics 66:503-512.

AMAP (ARCTIC MONITORING AND ASSESSMENT PROGRAMME). 1998. AMAP Assessment Report: Arctic Pollution Issues. Available from AMAP Secretariat, PO Box 8100 Dep, N-0032 Oslo, Norway.

AVERY,S.V.1996. Fate of caesium in the environment: Distribution between the abiotic and biotic components of aquatic and terrestrial ecosystems. Journal of Environmental Radioactivity 30:139-171.

BASKARAN, M., and NAIDU, A.S. $1995 .{ }^{210} \mathrm{~Pb}$-derived chronology, and the fluxes of ${ }^{210} \mathrm{~Pb}$ and ${ }^{137} \mathrm{Cs}$ isotopes into continental shelf sediments, East Chukchi Sea, Alaskan Arctic. Geochimica et Cosmochimica Acta 59:4435-4448.

BASKARAN, M., ASBILL, S., SANTSCHI, P., DAVIS, T., BROOKS, J., CHAMP, M., MAKEYEV, V., and KHLEBOVICH, V. 1995. Distribution of ${ }^{239,240} \mathrm{Pu}$ and ${ }^{238} \mathrm{Pu}$ concentrations in sediments from the $\mathrm{Ob}$ and Yenisey Rivers and the Kara Sea. Applied Radiation and Isotopes 46:1109-1119.

BASKARAN, M., ASBILL, S., SANTSCHI, P., BROOKS, J., CHAMP, M., ADKINSON, D., COLMER, M.R., and MAKEYEV, V. 1996. Pu, ${ }^{137} \mathrm{Cs}$ and excess ${ }^{210} \mathrm{~Pb}$ in the Russian Arctic sediments. Earth and Planetary Science Letters 140: 243-257.

BEASLEY, T.M., and HELD, E.E. 1971. Silver-108m in biota and sediments at Bikini and Eniwetok Atolls. Nature 230:450-451.

BEASLEY, T.M., COOPER, L.W., GREBMEIER, J.M., KILIUS, L.R., and SYNAL, H.A. 1997. ${ }^{36} \mathrm{Cl}$ and ${ }^{129} \mathrm{I}$ in the Yenesei, Kolyma, and Mackenzie Rivers. Environmental Science and Technology 31:1834-1836.

BECKER, P.R., MACKEY, E.A., DEMIRALP, R., SUYDAM, R., EARLY, G., KOSTER, B.J., and WISE, S.A. 1995. Relationship of silver with selenium and mercury in the liver of two species of toothed whales (Odontocetes). Marine Pollution Bulletin 30:262-271.

COOPER, L.W., GREBMEIER, J.M., LARSEN, I.L., SOLIS, C., and OLSEN, C.R. 1995. Evidence for re-distribution of cesium137 in Alaskan tundra, lake and marine sediments. The Science of the Total Environment 160/161:295-306.

COOPER, L.W., GREBMEIER, J.M., LARSEN, I.L., DOLVIN, S.S., and REED, A.J. 1998. Inventories and distribution of radiocesium in Arctic marine sediments: Influence of biological and physical processes. Chemistry and Ecology 15:27-46.

COOPER, L.W., BEASLEY, T., AAGAARD, K., KELLEY, J.M., LARSEN, I.L., and GREBMEIER, J.M. 1999. Distributions of the nuclear fuel-reprocessing tracers in the Arctic Ocean: Indications of Russian river influence. Journal of Marine Research 57:715-738.

EIKELMANN, I.M.H., BYE, K., and SLETTEN, H.D. 1990. Seasonal variation of cesium-134 and cesium-137 in semidomestic reindeer in Norway after the Chernobyl accident. Rangifer 3:35-38.

FISHER, N.S. 1985. Accumulation of metals by marine picoplankton. Marine Biology 87:137-142.

FOLSOM, T.R., GRISMORE, R., and YOUNG, D.R. 1970. Longlived $\gamma$-ray emitting nuclide silver $108 \mathrm{~m}$ found in Pacific marine organisms and used for dating. Nature 227:941-943.

GRISMORE, R., FOLSOM, T.R., HODGE, V.F., and YOUNG, D.R. 1972. A study of the radiosilver signature of the $1961-$ 1962 nuclear weapons testing period. Transactions of the New York Academy of Sciences, Series 2, 34:392-415.

HANSON, W.C. 1967. Cesium-137 in Alaskan lichens, caribou and Eskimos. Health Physics 13:383-389.

HAZARD, K. 1988. Beluga whale, Delphinapterus leucas. In: Lentfer, J.W., ed. Selected marine mammals of Alaska: Species accounts with research and management recommendations. Washington, D.C.: Marine Mammal Commission. 197-235. 
HUNTINGTON, H.P., MOSLI, J.H., and SHUSTOV, V. 1998. Peoples of the Arctic. In: AMAP Assessment Report: Arctic Pollution Issues. Available from AMAP Secretariat, PO Box 8100 Dep, N-0032 Oslo, Norway. 141-182.

KASAMATSU, F., and ISHIKAWA, Y. 1997. Natural variations of radionuclide ${ }^{137} \mathrm{Cs}$ concentration in marine organisms with special reference to the effect of food habits and trophic level. Marine Ecology Progress Series 160:109-120.

KERSHAW,P., and BAXTER, A. 1995. The transfer of reprocessing wastes from northwest Europe to the Arctic. Deep-Sea Research II, 42:1413-1448.

LARSEN, I.L. 1998. Suggestions and guidelines for the identification and quantification of radionuclides determined by gamma-ray spectrometry using semiconductor germanium detectors. Radioactivity and Radiochemistry 9:4-12.

LAUDEMAN, M.J., CONDRA, D., and SHIPLEY, S. 1995. Laboratory procedures manual for the Environmental Survey and Site Assessment Program. ORISE Report 95/A-65, Revision 9, Oak Ridge Institute for Science and Education, Oak Ridge, Tennessee 37831-0117, U.S.A.

LAYTON, D., EDSON, R., VARELA, M., and NAPIER, B. 1997. Radionuclides in the Arctic Seas from the Former Soviet Union: Potential Health and Ecological Risks. Arlington, Virginia: Office of Naval Research, Arctic Nuclear Waste Assessment Program.

LINDMAN, H.R. 1992. Analysis of variance in experimental design. New York: Springer-Verlag.

LIVINGSTON, H.D. 1988. The use of Cs and Sr isotopes as tracers in the Arctic Mediterranean Seas. Philosophical Transactions of the Royal Society. London, Series A, 325:161-176.

MACKEY,E.B., BECKER, P.R., DEMIRALP, R., GREENBERG, R.R., KOSTER, B.J., and WISE, S.A. 1996. Bioaccumulation of vanadium and other trace metals in livers of Alaskan cetaceans and pinnipeds. Archives of Environmental Contaminants and Toxicology 30:503-512.

MACDONALD, C.R., EWING, L.L., ELKIN, B.T., and WIEWEL, A.W. 1996. Regional variation in radionuclide concentrations and radiation dose in caribou (Rangifer tarandus) in the Canadian Arctic. The Science of the Total Environment 182:53-73.

MACDONALD, R.W., and BEWERS, J.M. 1996. Contaminants in the arctic marine environment: Priorities for protection. ICES Journal of Marine Science 53:537-563.
MEDINETS, V. I., SOLOVIEV, V. G., and GLEBOV, B. V. 1992. Investigation of cesium-137 distributions in seawater. In: Nagel, P.A., ed. Results of the Third Joint U.S.-U.S.S.R. Bering and Chukchi Seas Expedition (BERPAC), Summer 1988. Washington D.C.: U.S. Fish and Wildlife Service. 327-329.

O'HARA, T.M., DASHER, D., GEORGE, J.C., and WOSHNER, V. 1999. Radionuclide levels in caribou of northern Alaska in 1995-96. Arctic 52:279-288.

OLSEN, C.R., LARSEN, I.L., MULHOLLAND, P.J., VON DAMME, K.L., GREBMEIER, J.M., SCHAFFNER, L.C., DIAZ, R.J., and NICHOLS, M.M. 1993. The concept of an equilibrium surface applied to particle sources and contaminant distributions in estuarine sediments. Estuaries 16:683-696.

SCHEFFÉ, H. 1959. The analysis of variance. New York: John Wiley \& Sons.

STRAND, P., BALONOV, M., AARKROG, A., BEWERS, M.J., HOWARD, B., SALO, A., and TSATUROV, Y.S. 1998. Radioactivity. In: AMAP Assessment Report: Arctic Pollution Issues. Available from AMAP Secretariat, PO Box 8100 Dep, N-0032 Oslo, Norway. 525-619.

TULI, J.K. 1995. Nuclear wallet cards. Upton, New York: National Nuclear Data Center, U.S. Nuclear Data Network, Brookhaven National Laboratory.

VAKULOVSKY, S.M., KRYSHEV, I.I., NIKITIN, A.I., SAVITSKY, Y.V., MALYSHEV, S.V., and TERTYSHNIK, E.G. 1995. Radioactive contamination of the Yenesei River. Journal of Environmental Radioactivity 29:225-236.

WATSON, W.S., SUMNER, D.J., BAKER, J.R., KENNEDY, S., REID, R., and ROBINSON, I. 1999. Radionuclides in seals and porpoises in the coastal waters around the UK. The Science of the Total Environment 234:1-13.

YABLOKOV, A.V., KARASEV, V.K., RUMYANTSEV, V.M., KOKEYEV, M.Y., PETROV, O.I., LYSTSOV, V.N., YEMELYANKENKOV, A.F., and RUBTSOV, P.M. 1993. Fakty i problemy, svyazanniye s zachoroneniyem radioaktivnykh othodov v moryach, omyvaushchich territorii Rossiyskoy Federatsii (Facts and issues associated with radioactive waste disposal in seas bordering the Russian Federation.) (Materialy doklada Pravitelstvennoy komissii po voprosam, svyazannym s zachoroneniyem v more radioaktivnych otchodov, sozdannoy rasporyazheniyem Prezidenta Rossiyskoy Federatsii ot 24 oktyabrya 1992 g. No. 613 - rp.) Moscow: Administratsiya Prezidenta Rossiyskoy Federatsii. Translated by Paul Gallager and Elena Bloomstein. Albuquerque, New Mexico: Small World Publishers, Inc. 